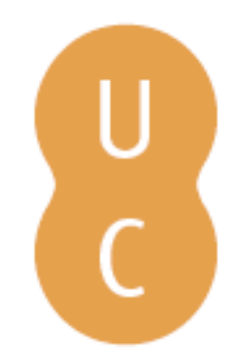

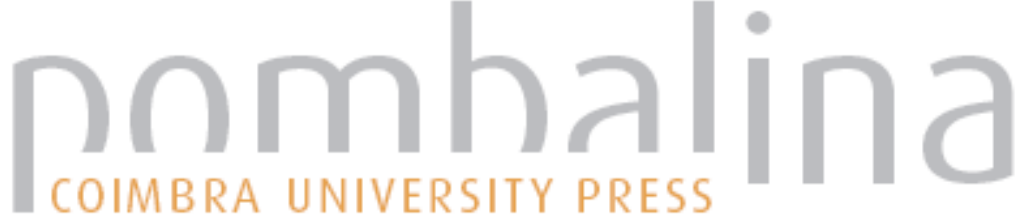

\section{O campo político dos partidos republicanos portugueses (1910-1926)}

\author{
Autor(es): Leal, Ernesto Castro \\ Publicado por: Imprensa da Universidade de Coimbra \\ URL \\ persistente: URI:http://hdl.handle.net/10316.2/31138 \\ DOI: $\quad$ DOI:http://dx.doi.org/10.14195/978-989-26-0497-8_10
}

Accessed : $\quad$ 26-Apr-2023 16:12:35

A navegação consulta e descarregamento dos títulos inseridos nas Bibliotecas Digitais UC Digitalis, UC Pombalina e UC Impactum, pressupõem a aceitação plena e sem reservas dos Termos e Condições de Uso destas Bibliotecas Digitais, disponíveis em https://digitalis.uc.pt/pt-pt/termos.

Conforme exposto nos referidos Termos e Condições de Uso, o descarregamento de títulos de acesso restrito requer uma licença válida de autorização devendo o utilizador aceder ao(s) documento(s) a partir de um endereço de IP da instituição detentora da supramencionada licença.

Ao utilizador é apenas permitido o descarregamento para uso pessoal, pelo que o emprego do(s) título(s) descarregado(s) para outro fim, designadamente comercial, carece de autorização do respetivo autor ou editor da obra.

Na medida em que todas as obras da UC Digitalis se encontram protegidas pelo Código do Direito de Autor e Direitos Conexos e demais legislação aplicável, toda a cópia, parcial ou total, deste documento, nos casos em que é legalmente admitida, deverá conter ou fazer-se acompanhar por este aviso.

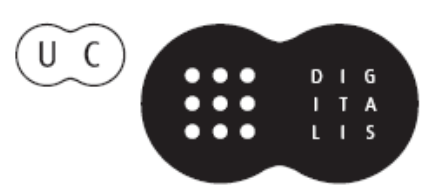


Armando Malheiro da Silva

Maria Luiza Tucci Carneiro

Stefano Salmi

Coordenação

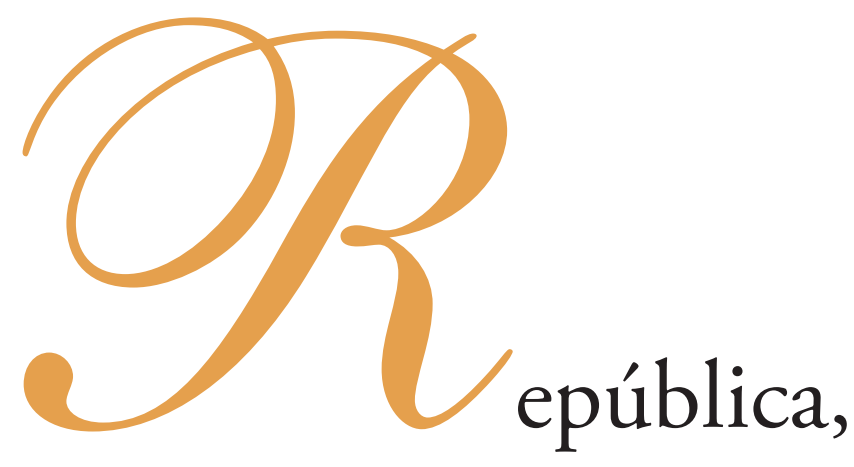

Republicanismo

e Republicanos

Brasil • Portugal • Itália 


\section{Ernesto Castro Leal}

\section{O CAMPO POLÍTICO DOS PARTIDOS REPUBLICANOS PORTUGUESES (1910-1926)}

O movimento republicano português, activado com as inaugurações do Centro Republicano Democrático em Abril 1876 e do Centro Republicano Federal em Janeiro de 1879, ambos radicados em Lisboa, havia de se constituir progressivamente em Partido Republicano Português, a partir do Congresso Republicano de Junho de 1883, reunido em Lisboa nas salas do Clube Henriques Nogueira. Aí nasceu a primeira direcção nacional do movimento, promotora da fundação do partido, que criou, até à revolução de 5 de Outubro de 1910, um espaço público republicano assente em jornais, folhetos e livros, centros políticos e centros escolares, campanhas cívicas (anticlericalismo, registo civil, laicismo, sufrágio universal, feminismo) e numa rede sócio-política de apoio (predominante nos centros urbanos mas de geografia nacional). A partir de 1907, em torno da contestação ao Governo de João Franco, acentuou a tensão revolucionária, entrelaçando com eficácia os quatro principais níveis dessa estratégia: candidaturas eleitorais e afirmação do activismo dos deputados e dos autarcas; contestação pública organizada pelas comissões políticas do partido e aguerrido publicismo; conspiração civil da Carbonária Portuguesa; conspiração militar no exército e na marinha. O horizonte da revolução republicana ganhava nitidez e Basílio Teles - doutrinador de uma ditadura revolucionária republicana ("ditadura consentida") para radicar a República - advertia, em meados de 1907: "As revoluções são o imprevisto: e num país como este, o 
imprevisto, se não é impossível que represente a sorte grande, é provável que seja um bilhete que saiu branco — uma desilusão e um prejuízo [...]"272.

A audiência da crítica radical à Monarquia e à dinastia de Bragança ultrapassava o campo político republicano, mas este, que tinha estruturado o Partido Republicano Português cada vez mais como um semi-partido de massas, onde se organizavam facções políticas, verdadeiros partidos de notáveis, ao redor dos seus chefes, redes sócio-políticas de apoio e respectivos periódicos - Afonso Costa com O Mundo, Manuel de Brito Camacho com A Lucta e António José de Almeida com a Alma Nacional e depois com o República —, estava politicamente dividido apesar da aparente unidade ideológica em torno do anticlericalismo e do antimonarquismo, sonhando com o messianismo prometeico da República ${ }^{273}$. Basílio Teles sinalizou um dos possíveis dilemas da situação pós-revolucionária, optando pela primeira alternativa: "[...] sustentar a República com sacrifício do programa, ou sustentar o programa com sacrifício da República [...]"274.

Este "partido-frente" de 1910 foi rememorado com perspicácia pelo republicano Manuel de Brito Camacho:

"Havia republicanos federalistas e unitários; parlamentaristas e presidencialistas; conservadores e liberais; descentralizadores na ordem administrativa e centralizadores até à tutela do município. Com respeito às relações do Estado com a Igreja, havia os partidários do regime concordatório, mantendo a Igreja, senão sob tutela, no menos sob a imediata e directa fiscalização do Estado, e havia os que reclamavam um regime de separação como veio a decretá-lo, mais tarde a França, sem renunciar à supremacia do poder civil'nzs.

${ }^{272}$ TELES, Basílio - I - As Ditaduras. II - O Regime Revolucionário [1911]. $2^{\mathrm{a}}$ ed. Coimbra: Atlântida Editora, 1975, p. 23.

${ }^{273}$ MEDINA, João - "Ob! a República!...". Estudos sobre o Republicanismo e a Primeira República Portuguesa. Lisboa: Instituto Nacional de Investigação Científica, 1990; CATROGA, Fernando - O Republicanismo em Portugal. Da Formação ao 5 de Outubro de 1910. Coimbra: Faculdade de Letras da Universidade de Coimbra, 1991; HOMEM, Amadeu Carvalho - Da Monarquia à República. Viseu: Palimage Editores, 2001.

${ }^{274}$ TELES, Basílio - op. cit., p. 18.

${ }^{275}$ A Lucta, Lisboa, $27^{\circ}$ ano, no 5498, 2 de Outubro de 1932, p. 1. 
O debate realizado na Assembleia Nacional Constituinte, entre Junho e Agosto de 1911, foi revelador dessa diversidade ideológica, apesar do Programa do Partido Republicano Português, aprovado em 11 de Janeiro de 1891 e ainda em vigor em 1910-1911, estipular na prática uma orientação de república federal e municipalista, legitimada no sufrágio directo universal, sem referência a um Presidente da República, cujo paradigma era em grande parte o regime político da Confederação Helvética. A Constituição promulgada a 21 de Agosto de 1911 veio consagrar, pelo contrário, uma república unitária, o sistema parlamentar com supremacia do Congresso da República, onde se elegia o Presidente da República, que não tinha o direito de dissolução parlamentar, e o sufrágio directo não universal, mantendo uma opção descentralizadora quanto à administração municipal e colonial, os princípios da democracia política e económica e da laicização do Estado e secularização da sociedade.

A reivindicação do princípio da dissolução parlamentar pelo Presidente da República, considerada fundamental no sistema de governo parlamentar, vai unir os partidos republicanos demoliberais moderados (Partido Republicano Evolucionista e União Republicana), que veriam finalmente a sua constitucionalização na Lei no 891, de 22 de Setembro de 1919, apesar de limitada pela consulta prévia de um Conselho Parlamentar — de facto, só constituído para a legislatura de 1922-1925, o que não impediu a dissolução parlamentar de 1921 —, e serviu também de argumento crítico para os republicanos radicais de matriz federalista, expresso, deste modo, por António Machado Santos:

"[...] os constituintes [...] esquivaram-se, com menos saber, a adoptar o princípio da dissolução das Câmaras, indispensável a um regime parlamentar, por muito se ter clamado contra a sua aplicação no tempo da monarquia, brindando-nos assim com um gáchis político que a inconsciência dos homens mais havia de agravar ainda'276.

O mesmo se pode afirmar em relação à hipótese de um rotativismo governamental, evitando os pronunciamentos militares que acompanharam a evolução do

\footnotetext{
${ }^{276}$ SANTOS, Machado - A Ordem Pública e o 14 de Maio. Lisboa: [Papelaria e Tipografia Liberty, Lamas \& Franklin], 1916, p. 5.
} 
regime republicano e lhe conferiram uma matriz permanentemente revolucionária. Devido à revisão ideológica do federalismo patrocinada pelos principais membros do directório do Partido Republicano Português e aceite pela grande maioria dos deputados constituintes, defensores do unitarismo republicano-liberal, de pendor jacobino, a contestação veio a ser protagonizada durante 1911-1913 por diversos grupos políticos radicais, defensores de um federalismo republicano-socialista, de pendor democrático.

\section{Fragmentação do Partido Republicano Português}

Momento decisivo para o desenvolvimento da ruptura entre as várias facções políticas dentro do Partido Republicano Português foi o da eleição do primeiro Presidente da República, Manuel de Arriaga (121 votos), no dia 24 de Agosto de 1911 (evocando a longínqua revolução liberal portuguesa de 24 de Agosto de 1820), apoiado pelas facções políticas de António José de Almeida, de Manuel de Brito Camacho e de António Machado Santos — o Bloco — contra o candidato Bernardino Machado (86 votos), com o apoio da facção política de Afonso Costa. No dia 1 de Setembro de 1911, constituiu-se o Grupo Parlamentar Democrático, afecto à facção política de Afonso Costa e três dias depois os democráticos aprovaram um extenso Projecto de Programa do Partido Republicano Português, com vastas medidas governamentais, justificadas em princípios do ideário político republicano português - esses princípios teriam formalizações distintas e, no caso do sufrágio directo universal (mesmo só o masculino), nunca seria consagrado durante o regime republicano parlamentarista (representou uma excepção o uso desse sufrágio em 1918 para a eleição do Presidente da República, Sidónio Pais, no seu regime republicano presidencialista): liberdades de pensamento, reunião, associação e de voto, defesa da Lei da Separação do Estado das Igrejas, sufrágio universal com o método da representação proporcional, referendo legislativo, ensino laico, políticas de desenvolvimento e de equilíbrio orçamental, serviço militar obrigatório, fortificação do triângulo estratégico do Atlântico (Lisboa, Açores, Cabo Verde) ou descentralização administrativa.

Iniciaram a criação de Centros Republicanos Democráticos em Lisboa, Porto e Coimbra, visando a formação nacional de estruturas organizativas e de 
uma rede sócio-política de apoio, com o objectivo imediato da realização do congresso de Lisboa do Partido Republicano Português, em Outubro de 1911, onde foi eleito um directório do partido totalmente afecto a essa facção política, confirmado no congresso de Braga de Abril de 1912. Quebrou-se assim definitivamente a unidade partidária dos republicanos históricos e iniciou-se a refundação do partido, após as cisões provocadas pelas facções políticas opositoras mais destacadas. O Partido Republicano Português passou a representar unicamente a facção política de Afonso Costa e o nome do partido nunca será revisto oficialmente até à sua extinção após a revolução de 28 de Maio de 1926, apesar de ter havido uma proposta apresentada no congresso do Porto de Dezembro de 1920 para o renomear como Partido Republicano Democrático; contudo, seria vulgarizado na opinião pública como Partido Democrático, decorrente da denominação do Grupo Parlamentar Democrático e dos Centros Republicanos Democráticos.

A convergência parlamentar dos bloquistas, que elegeu o Presidente da República, evoluiu durante os meses de Setembro e Outubro de 1911, já sem o apoio da facção política radical de António Machado Santos, para uma aliança parlamentar denominada União Nacional Republicana e alguma hesitação quanto à sua transformação em partido. Não obstante a promoção de um amplo movimento nacional de adesões e da estruturação de alguns centros políticos, a União Nacional Republicana sobreviveu apenas entre Novembro de 1911 e Fevereiro de 1912, dando lugar à organização separada de dois partidos. O Programa da União Nacional Republicana, aprovado em 20 de Dezembro de 1911, era antecedido de uma introdução justificativa, onde se afirmava o fim da "unidade do velho partido republicano histórico" depois da revolução republicana, situação previsível visto a unidade ter sido "uma convergência de forças imposta pela necessidade de produzir o mais rapidamente possível o máximo efeito útil". O novo grupo político fazia parte da inevitável pluralidade partidária republicana dos regimes demoliberais e os objectivos programáticos eram muito semelhantes aos dos democráticos, sendo recordado, num discurso mais moderado, a necessidade de corrigir os excessos "reaccionários e demagógicos" cometidos, preparar a cuidadosa revisão da obra legislativa revolucionária do Governo Provisório, assegurar a ampla liberdade de opinião e o direito de propriedade ou promover a reforma dos serviços públicos. 
O campo político republicano começava a institucionalizar partidariamente uma área mais radical, que tendia progressivamente para o monopólio exclusivista da representação política, e outra área mais moderada, que alimentava a ilusão de um rotativismo governativo à inglesa. O certo é que, durante todo o regime republicano, apesar da afirmação dominante do Partido Republicano Português, este foi obrigado em várias circunstâncias a celebrar acordos partidários de incidência parlamentar ou governamental, que se traduziram em governos de concentração republicana. A política republicana será representada, entre 1911 e 1917, pelas lideranças de Costa, Almeida e Camacho, que o escritor Raul Brandão retratou com elementos das suas psicologias políticas, vindo a ser fixados como máscaras por importantes sectores da opinião pública portuguesa:

"O Afonso Costa desperta paixões e manda, o António José arrasta multidões com frases. O Brito Camacho, até quando tem razão, é detestado-talvez mais detestado do que quando a não tem [.. . ]"277.

A mobilização do republicanismo radical e federalista foi protagonizada até 27 de Abril de 1913 - altura em que alguns radicais tentaram fazer um golpe de Estado para demitir o Governo de Afonso Costa — através de três grupos políticos: "Os Intransigentes", de António Machado Santos; Integridade Republicana, de João Bonança; Partido Republicano Radical Português, de Adrião Castanheira, Luís Soares e Henrique de Sousa Guerra. Destacou-se o primeiro, sob a chefia do herói da revolução de 5 de Outubro de 1910, que hesitou, entre o federalismo municipalista e corporativista e o presidencialismo unitário descentralista, estabelecendo relações com sectores sindicalistas e socialistas radicais, dado o pendor social e revolucionarista comum. Machado Santos fundou o jornal O Intransigente, "diário republicano radical", em 12 de Novembro de 1910, e propagandeou um republicanismo puro, que impusesse intransigência nos princípios democráticos, na selecção da classe política e na recusa dos que buscavam abrigo no novo regime, "sem terem formado a ideia à custa da experiência e guiados agora só

${ }^{277}$ BRANDÃO, Raul - Memórias. Vale de Josafat. vol. III. Lisboa: Perspectivas \& Realidades, s.d., p. 41. 
pelo interesse ou pelo medo"278, numa alusão aos denominados adesivos que estiveram em partidos monárquicos, que se converteram ao republicanismo após a revolução e que ocuparam de seguida alguns lugares institucionais de relevo.

Os intransigentes publicaram um Manifesto ao eleitorado português, em 15 de Maio de 1911, onde anunciaram o grupo político Aliança Nacional, que criou um Comité no Norte/Porto (presidido por Sampaio Bruno) e outro Comité no Sul/Lisboa (presidido por Machado Santos), tendo organizado uma fraca rede sócio-política de apoio. Quer a pressão feita pelo partido de Afonso Costa (onde havia um sector de cariz radical) e pelos partidos criados por António José de Almeida e Manuel de Brito Camacho, quer a conspiração permanente de Machado Santos (em particular contra os democráticos), serão circunstâncias negativas para a construção de uma área política muito marcada pelo peso da memória carbonária civil e do processo revolucionário antimonárquico. O grupo político de Machado Santos ressurgiu em 1914-1915 com o Centro Reformista e em 1919-1921 com a Federação Nacional Republicana.

\section{Estruturação do sistema de partidos}

Entre Setembro de 1911 e Fevereiro de 1912, lançaram-se as bases dos três primeiros partidos do republicanismo constitucional: Partido Republicano Português (democráticos), refundado, de Afonso Costa, que permaneceu até ao fim do regime político, Partido Republicano Evolucionista (evolucionistas), de António José de Almeida, e União Republicana (unionistas), de Manuel de Brito Camacho, que se extinguiram em Setembro de 1919. O congresso de Braga de Abril de 1912 aprovou o Programa do Partido Republicano Português, documento mantido inalterável até à Ditadura Militar de 1926, que era o mesmo do já referido projecto de programa de 1911 do Grupo Parlamentar Democrático. Herdando grande parte da máquina organizativa e das redes sócio-políticas republicanas históricas, disseminadas pelo território nacional, e importantes notabilidades

${ }^{278}$ FERREIRA, José Eugénio - "Ao País”. In O Intransigente. Lisboa, ano I, n 1, 12 de Novembro de 1910 , p. 1. 
e redes sócio-políticas monárquicas, os democráticos foram o mais importante partido de governo, nem sempre no poder, com destacada influência política.

Não admira, portanto, o paralelismo entre a sua evolução político-eleitoral e a do regime republicano, que já foi classificado como de multipartidarismo imperfeito ou de partido dominante ${ }^{279}$, onde o poder político, patrocinando um sistema de redes clientelares, tendia ao exercício "exclusivista" e "ininterrupto"280, interpretado por vezes como "uma ditadura do PRP" ou "ditadura democrática"281. Porém, não se deve esquecer a fragilidade ideológica, política e organizativa, a insuficiente dispersão nacional e raiz eleitoral, o mesmo clientelismo e caciquismo ou a rivalidade das chefias e das notabilidades locais nas principais propostas partidárias concorrentes, o que também ajudava ao domínio do Partido Republicano Português, à impossibilidade funcional da alternância política e à normal governabilidade, muitas vezes exercida em governos de coligação partidária.

O primeiro Governo de Afonso Costa (9 de Janeiro de 1913 a 9 de Fevereiro de 1914) teve o apoio dos unionistas, após António José de Almeida ter declinado a chefia governamental. Ao segundo Governo de Afonso Costa (29 de Novembro de 1915 a 15 de Março de 1916), sucedeu-lhe o Governo da União Sagrada entre democráticos e evolucionistas, presidido por António José de Almeida, com Afonso Costa em Ministro das Finanças. Os dois Governos de Afonso Costa revelam o núcleo da sua elite governamental nos inícios da I República: Interior (Rodrigo Rodrigues e Artur de Almeida Ribeiro), Justiça (Álvaro de Castro e João Catanho de Meneses), Finanças (Afonso Costa), Guerra (João Pereira Bastos e José Norton de Matos), Marinha (José de Freitas Ribeiro e Vítor de Azevedo Coutinho), Negócios Estrangeiros (António Macieira e Augusto Soares), Fomento (António Maria da Silva), Colónias (Artur de Almeida Ribeiro e Alfredo Rodrigues Gaspar) e Instrução Pública (António de Sousa Júnior e Frederico Ferreira de Simas).

A continuada presença dos democráticos nas estruturas do Estado e da administração pública central e local criou rotinas de centralismo burocrático,

${ }^{279}$ SOUSA, Marcelo Rebelo de - Os Partidos Políticos no Direito Constitucional Português. Braga: Livraria Cruz, 1983, pp. 167-177.

${ }^{280}$ LOPES, Fernando Farelo - Poder Político e Caciquismo na $1^{a}$ República Portuguesa. Lisboa: Editorial Estampa, 1994, pp. 161-164.

${ }^{281}$ VALENTE, Vasco Pulido - A República Velha, 1910-1917: ensaio. Lisboa: Gradiva, 1997. 
subalternizando a dinâmica de partido em relação à dinâmica de Estado, o que diluiu a autonomia partidária, o militantismo dos filiados, a capacidade de renovação ideológica ou a crítica livre. Mantendo uma plasticidade partidária assinalável, com algumas características de partido de militantes e semi-partido de massas, fomentadas pelas campanhas públicas laicistas e anticlericais, pelas associações, pelo clubismo, pelos centros escolares, pelo revolucionarismo civil de grupos legais (Batalhões de Voluntários) ou secretos (Formiga Branca), desenvolveu-se, cada vez mais, as características de um partido de cartel, pela ligação e manutenção às estruturas do poder, articuladas com características de partido de eleitores, ao que muito ajudava o peso da memória heróica da propaganda republicana, a capacidade oratória de alguns destacados dirigentes e a rede clientelar nacional, fidelizando a sua massa de apoio. No interior do Partido Republicano Português, além de ocasionais dissidências, que habitualmente regressavam - exemplo significativo foi o Grupo Parlamentar Democrático Dissidente de Domingos Leite Pereira em 1920-1921 _, ocorreram duas importantes cisões parlamentares que se organizaram em facção política e depois em partido político: a de Álvaro de Castro, com o Grupo Parlamentar de Reconstituição Nacional/Partido Republicano de Reconstituição Nacional (1920-1923); e a de José Domingues dos Santos, com o Grupo Parlamentar da Esquerda Democrática/Partido Republicano da Esquerda Democrática (1925-1926).

De 1910 a 1917, a figura mais destacada do Partido Republicano Português foi o jurisconsulto e professor universitário Afonso Costa, cuja acção como Ministro da Justiça do Governo Provisório - leis basilares da República (separação, família e divórcio) - e como Ministro das Finanças - equilíbrio orçamental e revisão da contribuição predial em 1913, estabilização cambial em 1915-1917 — o projectou por um lado, para líder político carismático de um certo radicalismo laicista republicano, por outro, para governante credível na área essencial das finanças públicas, com apoios na pequena e média burguesia urbana. Já quanto ao operariado urbano, em virtude de diversas medidas antigrevistas, sofreu uma forte oposição, capitalizada pelo republicanismo radical em convergência com anarco-sindicalistas e alguns socialistas, que o denominariam de racha-sindicalistas.

Nos anos 20, com o afastamento de Afonso Costa em Paris (continua a ser eleito membro efectivo do directório e deputado, entre 1919 e 1925), suceder-lhe-ia na liderança partidária o engenheiro António Maria da Silva, que era 
Presidente de Governo aquando da revolução de 28 de Maio de 1926, e que em 1922-1923 tentou desarticular o poder dos revolucionários civis em Lisboa conectados com forças da Guarda Nacional Republicana. Esta reposição do monopólio da violência no aparelho do Estado, através do corpo do exército, contou com o apoio dos Ministros da Guerra, António Correia Barreto, Ernesto Vieira da Rocha e Fernando Freiria. Realizaram 12 congressos partidários, em importantes áreas eleitorais do País, numa sequência quase anual, que deve ser relevada na capacidade política e organizativa: Outubro de 1911 (Lisboa), Abril de 1912 (Braga), Abril de 1913 (Aveiro), Maio de 1914 (Figueira da Foz), Março de 1915 (Lisboa), Julho de 1917 (Lisboa), Outubro de 1919 (Lisboa), Dezembro de 1920 (Porto), Abril de 1922 (Coimbra), Abril de 1923 (Lisboa), Abril de 1924 (Porto), Junho de 1925 (Lisboa). O jornal mais importante foi O Mundo até finais do primeiro semestre de 1925, altura em que passa a porta-voz da dissidência esquerda democrática, de José Domingues dos Santos; a partir dessa altura, o Partido Republicano Português usou o jornal O Rebate.

A 15 de Fevereiro de 1912, na Câmara dos Deputados, António José de Almeida e Manuel de Brito Camacho esclareceram que a União Nacional Republicana não representava a fusão das duas facções políticas, mas tão-só uma aliança parlamentar, aceitando António José de Almeida, transitoriamente, o programa da União Nacional Republicana, que, era, de facto, o do grupo de Manuel de Brito Camacho ${ }^{282}$. Em resposta, António Aresta Branco, secretário da União, enviou uma carta aos dois, demonstrando a sua mágoa por essa decisão. Estava criado o ambiente para uma nova constituição partidária: a 24 de Fevereiro surgiu o Partido Republicano Evolucionista, de António José de Almeida; a 26 de Fevereiro anunciou-se a União Republicana, de Manuel de Brito Camacho. As duas mais importantes cisões oriundas do histórico Partido Republicano Português não conseguiriam praticar uma eficaz convergência política.

Em 1925, Manuel de Brito Camacho, aquando do anúncio feito aos seus eleitores do distrito de Beja sobre a intenção de abandonar a actividade política, leu assim os tempos primordiais da República:

\footnotetext{
${ }^{282}$ A Lucta. Lisboa, $7^{\circ}$ ano, no 2215,17 de Fevereiro de 1912, p. 1.
} 
"Como lutar eficazmente, no campo da legalidade, contra o despotismo do Partido Democrático, exercendo o Poder em monopólio de facto? Fundindo os dois outros partidos, o unionista e o evolucionista, fusão que nada teria de artificial ou de absurdo, visto ambos serem ou se dizerem conservadores [...]"ns3.

O processo de fusão surgiria entre Setembro e Dezembro de 1919, consubstanciado no Partido Republicano Liberal, apesar da oposição de um sector evolucionista, dirigido por Júlio Martins, líder na Câmara dos Deputados, que dinamizará o Partido Republicano Popular.

O Partido Republicano Evolucionista prolongou a sua existência entre 1912 e 1919 e realizou três congressos partidários na cidade de Lisboa: Agosto de 1913, Abril de 1915 e Setembro-Outubro de 1919. O jornal República foi o seu mais importante órgão de imprensa e teve uma significativa rede de imprensa local. No dia seguinte à reunião magna de deputados e senadores afectos a António José de Almeida, realizada a 24 de Fevereiro de 1912, foi publicada no República uma moção, aprovada por unanimidade, a anunciar a criação do novo partido, cujo programa seria acentuadamente liberal e progressivo, assente nestes propósitos: reforma administrativa descentralizadora, nova lei eleitoral (representação proporcional em Lisboa e Porto e representação de minorias nos restantes círculos), revisão dos recenseamentos eleitorais, revisão dos diplomas com força de lei do Governo Provisório (separação entre o Estado e as Igrejas, instrução pública, exército, inquilinato, registo civil, assistência pública), amnistia política e militar, que serão desenvolvidos no programa partidário.

Os evolucionistas perfilhavam um método reformista — revendo António José de Almeida a anterior colocação política de pendor radical —, promoviam o consenso patriótico sobre o reconhecimento da Constituição, recusavam o radicalismo anticlerical e propunham a amnistia aos sindicalistas e monárquicos, desde que não fossem chefes de conspirações contra a República. Guiado por um critério de oposição às ditaduras militares, António José de Almeida adoptou uma posição política diferente perante o Governo extra-partidário e extra-parlamentar do general Pimenta de Castro, apoiado pelo Presidente da República, Manuel de Arriaga, e perante a Ditadura pós-revolucionária do major-lente Sidónio Pais.

${ }^{283}$ A Lucta. Lisboa, $20^{\circ}$ ano, $\mathrm{n}^{\circ} 5486,6$ de Setembro de 1925 , p. 1. 
Quanto ao primeiro, começou na expectativa e evoluiu para uma atitude de apoio crítico, recusando no entanto todos os procedimentos antiparlamentares e antirepublicanos praticados, em particular a partir de Março de 1915; quanto ao segundo, opôs-se frontalmente desde o início, fazendo parte da resistência parlamentarista demoliberal ao emergente presidencialismo republicano.

No Programa do Partido Republicano Evolucionista, inscreviam-se, entre outras, as seguintes reivindicações: revisão moderada da Lei da Separação do Estado das Igrejas, implementação da reforma da instrução pública e da reforma tributária (taxas progressivas e degressivas), impedimento de delegação de competências do poder legislativo no poder executivo, alargamento do sufrágio, descentralização administrativa, organização do Senado com representantes dos agrupamentos e interesses nacionais, concessão ao Presidente da República do direito de dissolução parlamentar, em "determinadas condições, como garantia do sistema parlamentar", organização de sindicatos operários ou o direito de voto às mulheres nas eleições administrativas. Alfredo Pimenta fez parte da comissão redactora desse programa e escreveu um longo texto ${ }^{284}$, com medidas para todas as áreas da governação, sistematizando nele princípios de reforma constitucional para dignificar o parlamentarismo republicano, pois afirmava que

"na impossibilidade de efectuar uma franca e permanente ditadura republicana [ideia de Basílio Teles], sujeita à apreciação nacional por outros meios que não sejam o da ficção parlamentar, entendemos que muito convém restringir as funções do Congresso [...]".

Alguns dos seus princípios não foram aprovados, estando, entre eles, a eleição directa do Presidente da República (mandato de dez anos), a independência do poder executivo face ao poder legislativo, permitindo ao Presidente da República a livre escolha de ministros, a restrição da atribuição parlamentar quanto à discussão e votação das medidas propostas pelo poder executivo e a elevação para 30 anos da capacidade eleitoral dos cidadãos.

\footnotetext{
${ }^{284}$ PIMENTA, Alfredo - "Um programa". In Política Portuguesa. Elementos para a solução da crise nacional. Coimbra: Moura Marques, 1913, pp. 283-298.
} 
O tempo político da União Republicana coincidiu com o do Partido Republicano Evolucionista, tendo sido efectivados na cidade de Lisboa, entre 1912 e 1919, três congressos partidários: Maio de 1915, Agosto de 1916 e Abril de 1918. O órgão oficial era A Lucta e tinham uma razoável imprensa local. Os unionistas pretendiam também a transformação reformista e moderada do Estado e da sociedade portuguesa, advertindo para a necessidade de um plano integrado de desenvolvimento económico (Manuel de Brito Camacho e Sidónio Pais, unionistas, foram os primeiros ministros do Fomento da República) e para a revisão dos aspectos radicalistas da obra legislativa do Governo Provisório. O Programa da União Republicana, discutido e aprovado na assembleia magna de deputados e senadores, que teve lugar no dia 27 de Março de 1912, era praticamente igual, com ligeiríssimas alterações formais, ao da União Nacional Republicana de 1911-1912. Em 17 de Novembro de 1912, numa festa política dos unionistas, Manuel de Brito Camacho discursou para justificar o novo projecto partidário ${ }^{285}$. Começou por afirmar que o histórico Partido Republicano Português tinha sido reorganizado pouco antes de 1910 "para a revolução" e mantê-lo íntegro depois "era correr o risco de o conservar isolado dentro da Nação".

Justificava-se assim a formação de vários partidos de governo, organizando correntes de opinião dentro da República, em torno de perspectivas políticas concorrentes.

Manuel de Brito Camacho apontava o objectivo do equilíbrio orçamental mas não esquecia os necessários investimentos na defesa nacional, na instrução pública e no fomento económico, para o que considerava

"indispensável um empréstimo de liquidação, para empregar uma frase de Basílio Teles, a liquidação entendendo-se principalmente com a extravagância da nossa divida multiforme e contratos de toda a ordem, que é preciso rever".

Advertiu também os governantes para que não governassem "com a Rua, ainda que ela seja o número", porque o "governo" é uma acção orgânica e o "número" é uma força inorganizada, produtora de agitações e tumultos que

285 CAMACHO, Brito - A Situação Política e os Partidos. Notável discurso proferido pelo dr.... em 17 de Novembro de 1912. Lisboa: Centro da União Republicana, s.d. 
acabavam quase sempre numa resposta ditatorial, seja uma "ditadura imposta" à Napoleão ou uma "ditadura consentida" à Basílio Teles. Terminou com o apelo à "educação da vontade", para criar a energia necessária na "fase de civilização que inauguramos em 5 de Outubro".

$\mathrm{Na}$ agenda política, os unionistas tomaram algumas atitudes relevantes, tais como a defesa de uma revisão constitucional que introduzisse o princípio da dissolução parlamentar pelo Presidente da República, de uma lei eleitoral que consagrasse o sufrágio universal masculino de maiores de 21 anos e da transparência da administração pública, a votação da amnistia, a rejeição da censura preventiva e de um Ministério do Trabalho (criado em Março de 1916) e declararam no Parlamento a oposição à apreensão de navios alemães, que motivou a declaração de guerra a Portugal, e à entrada imediata na frente europeia de guerra. Apoiaram o primeiro Governo de Afonso Costa até pouco tempo antes da demissão e colaboraram condicionalmente com os Governos de Pimenta de Castro (rompem em 13 de Maio de 1915, dia anterior ao da revolução dos democráticos contra esse Governo) e de Sidónio Pais (rompem em Março de 1918). A dissidência da União Republicana com o rumo presidencialista da "República Nova" traduziu-se nas demissões em 7 de Março dos Ministros Alberto de Moura Pinto (Justiça), António dos Santos Viegas (Finanças) e António Aresta Branco (Marinha), e no apelo à abstenção eleitoral nas eleições de 28 de Abril de 1918. Alguns filiados não aceitam estas posições, rompem com o partido e convergem na directriz presidencialista de Sidónio Pais.

Os unionistas agregaram importantes figuras da elite intelectual, técnica e militar, o que lhes deu uma importante audiência pública para a governabilidade republicana, no entanto, tal não se traduziu em capacidade eleitoral alternativa aos democráticos. Nesta área demoliberal moderada, os evolucionistas foram a primeira força política, mas a sua representação parlamentar ficava a muita distância da dos democráticos e com algum destaque em relação aos unionistas, só a nível dos deputados, visto que estes obtiveram ligeiramente mais senadores. Veja-se a seguinte amostra: Dezembro de 1912 (deputados: democráticos-60, evolucionistas-34, unionistas-25; senadores: democráticos-26, unionistas-15, evolucionistas-11), Dezembro de 1913 (deputados: democráticos-82, evolucionistas-36, unionistas-25; senadores: democráticos-27, unionistas-16, evolucionistas-10), Junho de 1915 (deputados: democráticos-106, 
evolucionistas-26, unionistas-15; senadores: democráticos-45, unionistas-11, evolucionistas-9).

Evolução do sistema de partidos

O período da Primeira Grande Guerra configurou um momento de complexificação ideológica e de reconstrução das áreas políticas, onde se inseriu a proposta modernista da revista Orpheu, evidenciando uma nova geração cultural, que oscilava entre o nacionalismo e o cosmopolitismo, alguns deles seduzidos pelo presidencialismo (Fernando Pessoa ou António Ferro) ${ }^{286}$. O debate sobre a participação portuguesa na frente europeia da guerra atravessou todo o espectro político, com várias posições fracturantes até à declaração de guerra do Império alemão a Portugal em Março de 1916287. Reestruturou-se o campo político monárquico — Integralismo Lusitano (1914), Partido Legitimista (1915) e Causa Monárquica (1915) — , e os católicos romanos criaram o Centro Católico Português (1917), ao mesmo tempo que são fundadas duas ligas patrióticas sob o signo do ressurgimento nacional e da unidade moral da Nação, juntando republicanos e monárquicos, de matriz tradicionalista e conservadora — Liga Nacional (1915-1918) e Cruzada Nacional D. Nuno Álvares Pereira (1918-1938)288.

O ideário republicano radical do grupo de António Machado Santos e sua rede sócio-política de apoio renasceu em Janeiro de 1914, através do Centro Reformista (vulgarizado como Partido Reformista), onde se destacavam, para além do líder, o seu irmão Augusto Machado Santos, José Carlos da Maia, José Correia Nobre França, João Paulo Macedo de Bragança e Franklim Lamas. Iniciaram a montagem do Núcleo Reformista de Lisboa e nos finais de Outubro desse ano constituiu-se o Núcleo Reformista do Porto. A prisão do líder durante a revolução de 14 de Maio de 1915, por ter apoiado o Governo ditatorial de

${ }^{286}$ LEAL, Ernesto Castro - António Ferro. Espaço político e imaginário social (1918-1932). Lisboa: Edições Cosmos, 1994.

${ }^{287}$ AFONSO, Aniceto; GOMES, Carlos de Matos (coord.) - Portugal e a Grande Guerra, 1914-1918. Lisboa: Edição do "Diário de Notícias", 2003.

${ }^{288}$ LEAL, Ernesto Castro - Nação e Nacionalismos. A Cruzada Nacional D. Nuno Álvares Pereira e as Origens do Estado Novo (1918-1938). Lisboa: Edições Cosmos, 1999. 
Pimenta de Castro, e a proibição do jornal O Intransigente, em 13 de Maio de 1915, levaram à extinção do Centro Reformista.

A constituição do Governo da União Sagrada (15 de Março de 1916 a 25 de Abril de 1917) fez-se com base na aliança entre os democráticos e os evolucionistas para a intervenção imediata na frente europeia da Grande Guerra, não conseguindo envolver unionistas, reformistas, socialistas e católicos. A crítica a essa convergência atravessou um dos partidos signatários do acordo, o Partido Republicano Evolucionista, provocando a criação de uma facção política, sob a direcção de António Egas Moniz, que dará origem nos finais de 1917 ao Partido Centrista Republicano. Com presença no Congresso da República e em várias zonas do País, devido ao número de dissidentes evolucionistas, os centristas ganharam alguma audiência nacional a partir de Outubro de 1917, mobilizando uma elite prestigiada que favoreceu o estabelecimento de uma estrutura mínima de um partido de quadros, republicano moderado, activado pelos jornais A Opinião e o Jornal da Tarde, até que, em Abril de 1918, se incorporaram no Partido Nacional Republicano.

O Programa do Partido Centrista Republicano, divulgado em 20 de Outubro de 1917, tinha como objectivo "formar um centro de atracção e convergência dentro do regime", unindo as forças liberais conservadoras, e propunham: aceitação da forma republicana do regime e do sistema de governo parlamentar com introdução do princípio da dissolução parlamentar nas atribuições do Presidente da República, "rodeada das necessárias cautelas"; manutenção da aliança inglesa e incremento das relações diplomáticas com o Brasil e a Espanha; protecção ao operariado pela regulamentação do trabalho, extensão dos seguros sociais à doença, velhice e invalidez, harmonização entre o capital e o trabalho; supremacia do poder civil, liberdade de cultos, reatamento das relações diplomáticas com a Santa Sé e celebração de uma concordata de separação; política de desenvolvimento assente numa rede de melhoramentos materiais, no aperfeiçoamento das estruturas comerciais e industriais, na dinamização dos mercados coloniais e numa reforma profunda das estruturas agrárias; renomeação das colónias em províncias, porque "nos parecem mais nossas e mais ligadas".

O processo de legitimação eleitoral da "República Nova" exigiu a criação de um novo partido para organizar as candidaturas governamentais às eleições legislativas de 28 de Abril de 1918, vindo a constituir-se o Partido Nacional 
Republicano, que recolheu grande parte dos dirigentes e estruturas do Partido Centrista Republicano, de Egas Moniz, juntando-se-lhes sectores da nova elite política, administrativa e militar seguidora do rumo republicano presidencialista de Sidónio Pais ${ }^{289}$. Nesse meteórico ano de 1918, vivido sob o espectro de tumultos e revoluções, os dirigentes nacionais republicanos não tiveram tempo, engenho e convergência suficiente para configurar organicamente e enraizar socialmente o partido. A liderança carismática e populista de Sidónio Pais e a preponderância do poder executivo e da elite governamental substituíram progressivamente a função legitimadora, de criação do consenso político, a função constituinte, de implementação institucional do regime, e a função mobilizadora, de activismo cívico de massas, que deviam pertencer às funções do partido: o governo e a administração pública predominaram em relação à política e ao partido. Sidónio Pais, acompanhado por um grupo de indefectíveis, foi-se expondo pelo País, alimentando uma perigosa deriva messiânica e ditatorial.

No fundo, o problema partidário remetia para a indecisão quanto ao regime e ao sistema político da nova República Presidencialista: sistema limitado de competição partidária (preferência pelo rotativismo de dois blocos partidários), sistema limitado com partido único (admissão de um pluralismo mitigado de índole autoritária) ou sistema fechado de partido único (monopartidarismo de índole totalitária)? Tudo indica que Sidónio Pais e o seu círculo mais próximo recusavam pelo menos a última hipótese, simulando, por vezes, um cesarismo bonapartista plebiscitário. Repare-se nesta afirmação de Sidónio Pais, proferida em 29 de Julho de 1918 :

"Ao contrário do que muita gente julga o Partido Nacional Republicano não é actualmente o único partido do governo. É certo que o Partido Nacional Republicano acompanha o governo na sua política altamente nacional e patriótica. Mas o governo não se apoia nele como não se apoia noutro qualquer pois não dispensa dedicações e apoios de gente de bem e sente que tem de procurar o verdadeiro apoio no sentir e na opinião quase unânime do povo português [...]"290.

\footnotetext{
${ }^{289}$ SILVA, Armando Malheiro da - Sidónio e Sidonismo. 2 vols. Coimbra: Imprensa da Universidade de Coimbra, 2006.

${ }^{290}$ Um Ano de Ditadura. Discursos e Alocuções de Sidónio Pais. Coligidos por Feliciano de Carvalho com um estudo político de João de Castro [Osório]. Lisboa: Lusitânia Editora, 1924, pp. 75-76.
} 
Porém, na última versão do projecto constitucional de Dezembro de 1918, ainda revista por Sidónio, consagrava-se um sistema de governo presidencialista democrático e bicameral (câmara política e câmara corporativa)

Pulverização do sistema de partidos

A personalidade que tentou manter a presença governamental das várias correntes de opinião sidonistas, após o assassinato de Sidónio Pais, foi o major João Tamagnini Barbosa, nomeado Presidente de Governo (23 de Dezembro de 1918 a 27 de Janeiro de 1919), mas a constituição do Governo de José Relvas (27 de Janeiro a 30 de Março de 1919) encerrou institucionalmente a experiência presidencialista autoritária republicana. Relvas conseguiu que os partidos republicanos presentes no seu Governo aceitassem "a representação da corrente republicana do Sidonismo", por intermédio de António Egas Moniz (Ministro dos Negócios Estrangeiros),

"o que evitará mais fermentos de desordem e de revolta", porém, reconhecia que à "semelhança dos franquistas e afonsistas, os sidonistas pur sang são terrivelmente sectários, e têm da política uma concepção personalista muito próxima do feiticismo. Não lhes toquem no ídolo, porque então tornam-se intratáveis [... $]^{\prime 291}$.

A ideia política sidonista, nas suas diversas variantes, não se extinguiu e notabilidades ligadas ao Partido Nacional Republicano promoveram o seu reencontro orgânico em torno de novos grupos políticos - Partido Republicano Conservador, Partido Nacional Republicano Presidencialista, Centro Republicano Dr. Sidónio Pais, Juventude Republicana Sidonista, Acção Nacionalista/Centro do Nacionalismo Lusitano - e de um periodismo de relevância pública, onde se destacou O Jornal, O Imparcial, Portugal, O Dezembrista, Ideia Nova, Alma Portuguesa e principalmente A Ditadura. Esta área política neosidonista continuou nas suas novas formulações organizativas o debate desenvolvido durante

\footnotetext{
${ }^{291}$ RELVAS, José - Memórias Políticas. vol. 2. Lisboa: Edições Terra Livre, 1978, p. 85.
} 
a "República Nova", em particular sobre a solução para a crise do modelo político liberal republicano e para a afirmação permanente do revolucionarismo militar e civil: correcção autoritária ou superação integral, continuando a ser viável a alternativa presidencialista republicana.

Restabelecido o regime republicano parlamentar, iniciou-se o processo da primeira fusão demoliberal moderada, velho sonho dos primórdios da I República, que envolveu evolucionistas, unionistas e centristas. Foram aprovadas, entre finais de Setembro e inícios de Outubro de 1919, as Bases dum programa partidário do futuro Partido Republicano Liberal, onde se destacavam os seguintes objectivos genéricos: união dos republicanos, educação política do povo, prestígio do poder judicial, melhoria da condição de vida e de trabalho dos operários, reforma fiscal, desenvolvimento económico, nação armada, descentralização colonial, neutralidade religiosa do ensino público, recusa da violência, revisão dos aspectos "inutilmente agressivos" da Lei da Separação do Estado das Igrejas, alargamento do sufrágio (com regulamentação do voto feminino), recenseamento eleitoral obrigatório e representação de classes no Senado.

Os liberais desenvolveram actividade entre Outubro de 1919 e Fevereiro de 1923, altura em que se fundiram com os reconstituintes, e realizaram três congressos partidários em Lisboa: Novembro de 1919, Dezembro de 1920 e Março de 1922. Pretenderam consubstanciar uma alternância política aos democráticos, mas só governaram autonomamente cerca de cinco meses nos Governos de Tomé de Barros Queirós (23 de Maio a 30 de Agosto de 1921) e de António Granjo (30 de Agosto a 19 de Outubro de 1921, data da noite sangrenta, em que foi assassinado Granjo e outros republicanos históricos). Os liberais estiveram representados através de Mesquita de Carvalho, Celestino de Almeida e Jorge Nunes na coligação com democráticos no Governo de Domingos Leite Pereira (21 de Janeiro a 8 de Março de 1920), onde também estavam dois independentes e um socialista, formaram o primeiro Governo de António Granjo em coligação com os reconstituintes (19 de Julho a 20 de Novembro de 1920) e ganharam as eleições legislativas de 10 de Julho de 1921 (deputados: liberais-79, democráticos-54, reconstituintes-12; senadores: liberais-32, democráticos-22, reconstituintes-7).

Após a revolução republicana radical de 19 de Outubro de 1921 — donde saiu o outubrismo radical —, que sobressaltou as forças republicanas constitucionais, criou-se um ambiente favorável à convergência entre democráticos, liberais 
e reconstituintes para a formação de um Governo de coligação, contudo, apesar de ser aprovado um detalhado Programa de realizações imediatas ${ }^{292}$, em 29 de Novembro de 1921, tal não veio a concretizar-se. Os democráticos ganhariam destacados as eleições legislativas de 29 de Janeiro de 1922 (deputados: democráticos-71, liberais-33, reconstituintes-17; senadores: democráticos-37, liberais-11, reconstituintes-10), consolidando a hegemonia no sistema político e no sistema administrativo, através dos três consecutivos Governos de António Maria da Silva (6 de Fevereiro de 1922 a 15 de Novembro de 1923).

A renovação do republicanismo radical fez-se a partir de 1919 através de vários grupos políticos. Alguns deputados evolucionistas, dirigidos por Júlio Martins, não aceitaram o compromisso que deu origem ao Partido Republicano Liberal. A eles se juntaram deputados democráticos e independentes, originando em 8 de Outubro de 1919 o Grupo Parlamentar Popular, que Júlio Martins assim caracterizou:

"Na extrema esquerda da República nos encontramos, afastados do conservantismo que estagna, mas bem distantes dos extremismos rubros, negativistas de todo o existente [...], daqui erguemos o pendão do nosso radicalismo, dando à politica novos processos, em caminho de novas finalidades [...]. É nosso intuito organizar em Portugal as forças radicais da República e constituir com elas um núcleo forte capaz de entregá-las aos republicanos [...]"²3.

A projecção pública do grupo parlamentar permitiu que, em 23 de Maio de 1920, Júlio Martins anunciasse a criação do Partido Republicano Popular, para evitar "a tentativa de ressurgimento do dualismo político" inspirado no tempo da Monarquia Constitucional, e a sua Plataforma Política ${ }^{294}$.

Entre as medidas governativas, estavam o saneamento do exército, as reformas judiciária, financeira (restrições ao consumo, reforma fiscal com tributação mais alta das grandes propriedades e das grandes companhias), agrária (incentivar o regresso à terra, adubos para a lavoura), colonial (aprofundar a descentralização) e do ensino (especial atenção ao ensino agrícola), o fomento económico

\footnotetext{
${ }^{292}$ BARBOSA, José - O Problema Económico e Financeiro. (Alguns aspectos e soluções). Lisboa: Portugal-Brasil Ld ${ }^{a}$, Sociedade Editora, s.d. [1922], pp. 223-230.

${ }^{293}$ MARTINS, Júlio - "A nossa atitude". In O Popular. Lisboa, ano I, no 1, 21 de Janeiro de 1920, p. 1.

${ }^{294}$ O Popular. Lisboa, ano I, n 81, 24 de Maio de 1920, pp. 1-2.
} 
(industrialização das nossas matérias-primas, concentração das indústrias, nacionalização das minas e caminhos de ferro) e o combate ao clericalismo, respeitando as crenças íntimas. Os populares participaram em Governos de coligação com democráticos, dissidentes democráticos e reconstituintes, durante 1920-1921, vindo a extinguir-se o partido em Outubro de 1921, sem ter conseguido realizar um congresso partidário.

De Outubro de 1920 a Outubro de 1921, o grupo político de António Machado Santos esboçou novamente a sua estruturação em torno de uma Federação Nacional Republicana ("agremiação de política reformista"). O assassinato do líder na noite sangrenta de 19 de Outubro de 1921 interrompeu definitivamente essa intenção, reaparecendo alguns dos seus amigos políticos, a partir de 1923, no Partido Republicano Radical. Apesar de adoptarem a designação oficial de reformistas, eram republicanos radicais e aprovaram, em 26 de Dezembro de 1920, uma Lei Orgânica, da qual constavam estes princípios políticos: restabelecimento da ordem; ligação económica com as regiões da "antiga Lusitânia"; transformação das províncias ultramarinas em estados autónomos para, em conjunto com o território continental, se constituir um Estado Confederado Português; estreitamento das relações com o Brasil, tendo em vista a sua incorporação no Estado Confederado; relançamento da hegemonia portuguesa junto dos povos "descobertos" nos séculos XV e XVI. A matriz ideológica e orgânica filiava-se no republicanismo federalista e municipalista que inspirara o programa republicano de 1891.

Dentro desta área ideológica a proposta mais consistente foi representada pelo Partido Republicano Radical, entre 1923 e 1926, que reuniu sectores radicais outubristas, populares, reformistas, democráticos e independentes, onde coexistiu, sob a liderança inicial de José Pinto de Macedo, Alberto da Veiga Simões, Albino Vieira da Rocha, António de Almeida Arez, César Procópio de Freitas, João da Câmara Pestana e Orlando Marçal, uma forte corrente unitarista descentralizadora com uma significativa corrente federalista descentralizadora. Nem o estímulo vindo de França, com Édouard Herriot, Presidente do Partido Radical francês, nomeado Presidente de Governo (15 de Junho de 1924 a 10 de Abril de 1925), impediu que os radicais tivessem uma existência atribulada, fraccionista e de pouca expressão eleitoral para a governabilidade, com a disputa entre sectores constitucionalistas e revolucionaristas. Criaram uma importante rede sócio-política de apoio e realizaram quatro congressos partidários: Junho de 1923 
(Lisboa), Janeiro-Fevereiro de 1924 (Porto), Janeiro-Fevereiro de 1925 (Coimbra) e Março de 1926 (Lisboa).

O Programa do Partido Republicano Radical, aprovado no primeiro congresso de 1923, da autoria de José Pinto de Macedo, apontava a republicanização do regime, a morigeração da vida pública, a prática da competência no exercício das actividades públicas, a formulação de um plano combinado de reformas, o que exigia a prévia renovação do modelo republicano de Estado unitário: Presidente da República com poderes bem definidos, sendo, de facto, o chefe do poder executivo; Câmara Legislativa única; transformação do Senado numa Câmara da Economia Nacional, com representantes dos interesses regionais e profissionais; município autónomo, província como federação de concelhos e distritos correspondendo à área das províncias. No terceiro congresso de 1925, uma comissão presidida pelo coronel Alexandre Mourão, membro do directório, propôs a Tese sobre a constituição do Estado ${ }^{295}$, de matriz federalista, que foi aprovada: Assembleias de Freguesias (elegem as Juntas de Freguesias); Assembleias Municipais (elegem as Câmaras Municipais e representantes às Assembleias Provinciais); Assembleias Provinciais (elegem órgãos executivos); Colégio Presidencial, constituído pelos membros dos órgãos executivos provinciais, donde saía, rotativamente, por eleição anual ou bienal, um Presidente, que era o representante da Nação e um Vice-Presidente, que presidia às Assembleias Provinciais. Não elegeram nenhum deputado ou senador nas eleições legislativas de 8 de Novembro de 1925.

A primeira cisão nos democráticos ocorreu em 9 de Março de 1920, dando origem no Parlamento ao Grupo Republicano de Reconstituição Nacional, que promoveu a partir de Junho de 1920 a criação do Partido Republicano de Reconstituição Nacional, sob a liderança de Álvaro de Castro, extinguindo-se o partido em Fevereiro de 1923. A cisão da facção política de Álvaro de Castro consumou-se após não ter reunido os apoios parlamentares para constituição de um Governo extra-partidário ou de concentração, tendo sido mandatado pelo Presidente da República, em 6 de Março de 1920. Se esse foi o factor imediato da cisão, não se pode esquecer a controvérsia entre facções políticas mais radicais ou mais moderadas dentro dos democráticos, sobre a tolerância política e

${ }^{295}$ Renovação. Coimbra, ano I, no 32,31 de Janeiro de 1925 , p. 5. 
religiosa, o centralismo do Estado, o municipalismo e o regionalismo, a questão social ou o princípio presidencial de dissolução parlamentar. No Manifesto "Ao País" dos reconstituintes, divulgado a 3 de Abril de 1920, anunciava-se a finalidade de reconstituição nacional sob a supremacia do poder civil e com larga visão sobre as reformas sociais, dado "o avanço do socialismo" que "nenhum governo, nenhum regimen dele se podem desinteressar". Justificavam a necessidade do novo grupo, quer pelo ambiente europeu de transformação nos partidos políticos (Inglaterra, França, Espanha ou Itália), quer pela incapacidade renovadora dos democráticos, onde se manifestavam, segundo os cisionistas, lógicas oligárquicas de poder e práticas políticas defensoras da violência e da limitação das liberdades. A nova solução republicana devia reorganizar o regime, recusando "sobrepor à ideia da nação a ideia dos partidos, deles tudo fazendo depender".

O diário lisboeta A Vitória, porta-voz do grupo, em 1 de Agosto de 1920, publicou o Projecto de Programa do Partido Republicano de Reconstituição Nacional, onde se inscreviam, entre outras, estas políticas governamentais: função organizadora da actividade nacional do Estado, negando-lhe competência empreendedora industrial, comercial e agrícola; incentivo à iniciativa privada e às parcerias com o Estado através de concessões; definição de um plano de fomento com base em estudos elaborados por técnicos habilitados; redução da circulação fiduciária e uma política proteccionista através de pautas aduaneiras; criação de sociedades regionais de pomicultura e horticultura; execução de uma rede portuária e continuação do plano rodoviário; redução dos quadros do funcionalismo civil e simplificação dos serviços públicos; substituição gradual dos impostos indirectos pelos directos; empréstimos internos e externos devidamente estudados; aproximação de operários e patrões em uniões ou sindicatos com capacidade de regulação de interesses; independência absoluta do poder judicial; despolitização do exército, com a sua profissionalização; tolerância político-social e liberdade religiosa; regionalismo. Após a tentativa falhada do reconstituinte Alfredo de Sá Cardoso constituir um Governo de coligação, em 12 de Julho de 1920, Álvaro de Castro teria quatro meses depois praticamente o mesmo destino, pois o seu Governo de coligação entre reconstituintes, populares e dissidentes democráticos durou apenas de 20 a 30 de Novembro de 1920. Os reconstituintes participaram com alguns ministros em vários Governos de coligação em 1920-1922. Não conseguiram realizar 
um congresso partidário, apesar do seu anúncio para a segunda quinzena de Janeiro de 1922.

As negociações entre o Partido Republicano Liberal e o Partido Republicano de Reconstituição Nacional para a segunda fusão demoliberal moderada iniciaram-se em 3 de Maio de 1922, através do encontro de Tomé de Barros Queirós (liberal) com Álvaro de Castro (reconstituinte) ${ }^{296}$. Prosseguiram no segundo semestre e, em 7 de Fevereiro de 1923, foi assinado o Manifesto "Ao País" que colocava o Partido Republicano Nacionalista na área constitucionalista (respeito pelo estatuto constitucional do Estado), nacionalista (respeito pelas tradições nacionais) e moderada (tolerância no governo do povo). Evidenciou-se desde o início um frágil compromisso entre as três principais facções políticas e suas redes sócio-políticas de apoio, lideradas por Francisco da Cunha Leal, Álvaro de Castro e António Ginestal Machado. A controvérsia começou em torno do nome do partido: Júlio Dantas, com apoio de Álvaro de Castro, tinha proposto o nome de Partido Republicano Constitucionalista, mas consagrou-se Partido Republicano Nacionalista. Em Janeiro de 1924, publicaram um Programa de realizações imediatas, donde se selecciona estes tópicos: revisão constitucional para consagrar a livre prerrogativa presidencial de dissolução parlamentar, a representação corporativa no Senado e a criação do Conselho de Estado; assegurar a efectiva liberdade das religiões; redução das despesas públicas, reformulação do sistema retributivo, lançamento de empréstimos internos, obtenção de empréstimos externos a longo prazo; recusa do intervencionismo económico estatal e do exagerado proteccionismo; remodelação das leis do trabalho, indo ao encontro de reivindicações operárias; permanência da Aliança inglesa e necessidade de acordos comerciais diversificados; autonomia colonial e apoio às missões religiosas portuguesas; criação do ensino infantil, reorganização do ensino médio e promoção da autonomia universitária.

Esta nova proposta alternativa aos democráticos não obteve sucesso maioritário nas eleições legislativas de 8 de Novembro de 1925, como se observa nesta amostra: deputados (democráticos-83, nacionalistas-36, independentes-19) e senadores (democráticos-39, nacionalistas-8, independentes-8). Constituíram Governo apenas durante um mês (15 de Novembro a 18 de Dezembro de 1923),

\footnotetext{
${ }^{296}$ A Lucta . Lisboa, $17^{\circ}$ ano, $\mathrm{n}^{\circ} 5314,4$ de Maio de 1922, p. 1.
} 
sob a presidência de António Ginestal Machado, sendo um dado significativo a presença do general Óscar Carmona como Ministro da Guerra, futuro Presidente da República no "Estado Novo". Realizaram quatro congressos partidários, todos em Lisboa: Março de 1923, Janeiro de 1924, Março de 1925 e Março de 1926. Em 1925, aderem os membros do Partido Nacional Republicano Presidencialista, extinguindo-se então esse partido neosidonista.

A primeira cisão nos nacionalistas teve origem na decisão dos seus órgãos dirigentes, em 15 de Dezembro de 1923, de repudiar governos de coligação e "pseudo-governos nacionais", posição contrária à dos antigos reconstituintes, da facção política de Álvaro de Castro, que, nesse dia, se demitiu do partido. Dois dias depois, Alberto Xavier anunciou, na Câmara dos Deputados, o novo Grupo Parlamentar de Acção Republicana, reagrupando antigos reconstituintes e independentes, que não evoluiu para um partido, por recusa de Álvaro de Castro e seus amigos políticos. Este presidiu a um Governo (18 de Dezembro de 1923 a 6 de Julho de 1924), com democráticos, independentes e seareiros, e afirmou na sua apresentação, em 21 de Dezembro de 1923, a urgência de reforçar a autoridade do Estado e a função legislativa do poder executivo:

"A crise financeira do Estado atingiu um grau excepcional de gravidade. Deixou-se até hoje ao Poder Legislativo, quase exclusivamente, a responsabilidade de a resolver, quando é certo que os Parlamentos têm concedido ao Poder Executivo amplas autorizações para o atenuar. É outra orientação do Governo, que vai desde já usar dos meios legais ao seu alcance para efectivar, ao lado duma rigorosa diminuição de despesas, uma cuidadosa arrecadação de receitas, ficando ao Parlamento, claro está, o apreciar como entenda o uso desses meios se fizer [... ."297.

O novo grupo sobreviveu até 1925 e oscilou nos acordos parlamentares entre os democráticos e os nacionalistas.

A segunda cisão nos nacionalistas ocorreu em 7 de Março de 1926 - segundo dia do quarto congresso partidário - e foi protagonizada pela facção política de Francisco da Cunha Leal-José Mendes Cabeçadas Júnior e sua rede sócio-

${ }^{297}$ Diário da Câmara dos Deputados, sessão nº 15, de 21 de Dezembro de 1923, p. 7. 
-política de apoio, que fundou a União Liberal Republicana, pequeno mas dinâmico partido promotor de uma forte corrente republicana conservadora dentro da conspiração civil e militar que organizou a revolução de 28 de Maio de 1926. No Manifesto-Programa "Ao País", de 15 de Março de 1926, os liberais republicanos defendiam o respeito pelas aspirações da consciência católica (personalidade jurídica da Igreja, princípio da hierarquia religiosa, liberdade de ensino religioso nas escolas particulares), o reforço da Aliança inglesa e uma maior presença internacional, a revisão constitucional (independência e coesão dos vários poderes, Senado corporativo), uma reforma administrativa descentralizadora e a autonomia administrativa e financeira dos Açores e da Madeira, o rigor nas leis das incompatibilidades e da responsabilidade ministerial, a valorização económica das colónias, uma reforma fiscal (eficaz compressão das despesas, simplificação e melhor repartição do regime tributário), um programa de desenvolvimento global da economia, o regime de liberdade para a indústria e comércio tabaqueiro, o equilíbrio de classes, a melhoria das condições sociais ou a dignificação das Forças Armadas. Da sua elite dirigente, saiu um sector destacado que aderiu ao "Estado Novo": Albino dos Reis, Fernando Bissaya Barreto, Artur Ribeiro Lopes, Joaquim Lança, Jorge Botelho Moniz, Teófilo Duarte ou Eurico Cameira.

A última proposta partidária emergente, antes do colapso da I República, decorreu da segunda cisão nos democráticos, em 21 de Julho de 1925, dando origem ao Grupo Parlamentar da Esquerda Democrática, e evoluiu em Abril de 1926 para o Partido Republicano da Esquerda Democrático, liderado por José Domingues dos Santos. Propunham uma revisão ideológica de cariz socializante do ideário republicano, exposta no Manifesto "À Nação", de Outubro de 1925: extinção dos monopólios estatais do tabaco, fósforos e moagem, parcelamento dos latifúndios, democratização da República, reforma da educação nacional, reorganização económico-financeira, promoção social das classes médias e das classes trabalhadoras. Sem grande expressão no Congresso da República - seis deputados e um senador, após as eleições de 8 de Novembro de 1925 - realizaram um único congresso partidário, em Lisboa, no mês de Abril de 1926, onde José Domingues dos Santos apresentou a tese O Problema Político ${ }^{298}$. Evocando o programa republicano de 1891, que tinha uma matriz federalista descentralizadora, e a utopia

${ }^{298}$ A Choldra. Lisboa, ano I, no 14 (Suplemento), 1 de Maio de 1926. 
da república social, constante do programa dos socialistas, o líder da esquerda democrática, nessa tese, após considerar que os democráticos se tinham transformado numa "agência de negócios em véspera de falência fraudulenta", propunha a criação de um novo partido que traduzisse "fielmente a grande e profunda sentimentalidade da esquerda republicana”. Não se pronunciava abertamente sobre o federalismo, mas aderia a um unitarismo fortemente descentralizador, que reconhecesse a dignidade da pessoa humana ("base moral da Democracia"), o sufrágio universal ("condição essencial da Democracia”), as liberdades públicas e privadas, o unicameralismo, o sistema eleitoral proporcional com representação das minorias, a prioridade à instrução pública e ao desenvolvimento económico. Tiveram o apoio dos jornais O Mundo, A Choldra e A Capital.

\section{Bibliografia}

CANOtilho, J.J. Gomes - "Partidos políticos". In BARRETO, António; MÓniCA, Maria Filomena (coord.) - Dicionário de História de Portugal. Suplemento, vol. IX. Porto: Livraria Figueirinhas, 2000, pp. 30-35.

CATROGA, Fernando - O Republicanismo em Portugal: Da Formação ao 5 de Outubro de 1910. Coimbra, Faculdade de Letras da Universidade de Coimbra, 1991 (2 a ed., Lisboa: Editorial Notícias, 2000).

HOMEM, Amadeu Carvalho - A Ideia Republicana em Portugal. O contributo de Teófilo Braga. Coimbra: Livraria Minerva, 1989.

HOMEM, Amadeu Carvalho - Da Monarquia à República. Viseu: Palimage Editores, 2001.

LEAL, Ernesto Castro - António Ferro. Espaço político e imaginário social (1918-1932). Lisboa: Edições Cosmos, 1994.

LEAL, Ernesto Castro - Nação e Nacionalismo. A Cruzada Nacional D. Nuno Álvares Pereira e as Origens do Estado Novo (1918-1938). Lisboa: Edições Cosmos, 1999.

LEAL, Ernesto Castro - "A ideia federal no republicanismo português (1910-1926)". In Revista de História das Ideias, vol. 27, Coimbra: 2006, pp. 251-291.

LEAL, Ernesto Castro - Partidos e Programas. O campo partidário republicano português (1910-1926), Coimbra, Imprensa da Universidade, 2008.

LOPES, Fernando Farelo - Poder Político e Caciquismo na $1^{a}$ República Portuguesa. Lisboa: Editorial Estampa, 1994.

MACEDO, Jorge Borges de - "Republicano Português (Partido)". In Verbo. Enciclopédia Luso-Brasileira de Cultura, $16^{\circ}$ vol. Lisboa-São Paulo: Editorial Verbo, 1974, cols. 365-369.

MARQUES, A.H. de Oliveira (coord.) - Portugal da Monarquia para a República, vol. XI, Nova História de Portugal (direcção de Joel Serrão e A.H. de Oliveira Marques). Lisboa: Editorial Presença, 1991. 
MARTINS, Hermínio - "O colapso da I República" [1970]. In Classe, Status e Poder e outros ensaios sobre o Portugal contemporâneo. Lisboa: Imprensa de Ciências Sociais, 1998, pp. 69-98.

MEDINA, João - “Oh! a República!...”. Estudos sobre o Republicanismo e a Primeira República Portuguesa. Lisboa: Instituto Nacional de Investigação Científica, 1990.

MEDINA, João - O "Presidente-Rei" Sidónio Pais. Estudos sobre Sidónio Pais e o seu Consulado. Lisboa: Livros Horizonte, 2007.

SILVA, Armando Malheiro da - Sidónio e Sidonismo. 2 vols. Coimbra: Imprensa da Universidade de Coimbra, 2006.

SOUSA, Marcelo Rebelo de - Os Partidos Políticos no Direito Constitucional Português. Braga: Livraria Cruz, 1983.

TORGAL, Luís Reis - António José de Almeida e a República: Discurso de uma vida ou vida de um discurso. Lisboa: Círculo de Leitores, 2004.

VALENTE, Vasco Pulido - A República Velha, 1910-1917: ensaio. Lisboa: Gradiva, 1997. 